\title{
Status kebersihan gigi dan mulut berdasarkan cara menyikat gigi dengan teknik kombinasi pada anak kidal dan non-kidal
}

\author{
${ }^{1}$ Novany Lumempouw \\ ${ }^{2}$ Christy N. Mintjelungan \\ ${ }^{2}$ Kustina Zuliari \\ ${ }^{1}$ Kandidat Skripsi Program Studi Pendidikan Dokter Gigi Fakultas Kedokteran \\ ${ }^{2}$ Program Studi Pendidikan Dokter Gigi Fakultas Kedokteran \\ Universitas Sam Ratulangi Manado \\ Email: nlumempouw@gmail.com
}

\begin{abstract}
During the developmental stage, children begin to do a variety of activities including tooth brushing. Generally, children use their right hands dominantly to do their activities (right-handed), however, there are also children who use their left hands (lefthanded) dominantly. This study was aimed to assess the oral hygiene status based on tooth brushing with a combination technique among left-handed and right-handed children. This was a descriptive study with a cross-sectional design. Population study consisted of lefthanded and right-handed children at Kalawat, North Minahasa, North Sulawesi province. Respondents were 60 children consisted of 30 left-handed children and 30 right-handed children obtained by using the purposive sampling method. Data were obtained by using checking form of oral hygiene status. The results showed that oral hygiene status of most lefthanded and right-handed children was in good category. The average of OHI-S score of the left-handed children before tooth brushing was 0.7 and after tooth brushing was 0.3 , whereas, of the right-handed children, the average of OHI-S score before tooth brushing was 0.6 and after tooth brushing was 0.2. Conclusion: Oral hygiene status of right-handed children who brushed their teeth with a combination technique was better than of the left-handed children.

Keywords: oral hygiene status, left-handed children, right-handed children, tooth brushing, combination technique
\end{abstract}

\begin{abstract}
Abstrak: Seiring berjalannya tahap perkembangan, anak-anak mulai melakukan aktivitas termasuk menyikat gigi. Umumnya anak dominan melakukan aktivitas menggunakan tangan kanan (non-kidal) tetapi ada juga yang dominan melakukan aktivitas menggunakan tangan kiri (kidal). Penelitian ini bertujuan untuk mendapatkan status kebersihan gigi dan mulut nerdasrkan cara menyikat gigi dengan teknik kombinasi pada anak kidal dan non-kidal. Jenis penelitian ialah deskriptif dengan desain potong lintang. Populasi penelitian ialah anak kidal dan non-kidal di Kecamatan Kalawat Kabupaten Minahasa Utara Provinsi Sulawesi Utara. Jumlah responden sebanyak 60 orang anak terdiri dari 30 anak kidal dan 30 anak non-kidal diambil dengan metode purposive sampling. Pengumpulan data menggunakan formulir pemeriksaan status kebersihan gigi dan mulut. Hasil penelitian menunjukkan status kebersihan gigi dan mulut pada anak kidal dan anak non-kidal sebagian besar memiliki kategori baik. Rerata skor OHI-S anak kidal sebelum menyikat gigi yaitu 0,7 dan sesudah menyikat gigi 0,3 sedangkan pada anak non-kidal rerata skor OHI-S sebelum menyikat gigi 0,6 dan sesudah menyikat gigi 0,2. Simpulan: Status kebersihan gigi dan mulut berdasarkan cara menyikat gigi menggunakan teknik kombinasi pada anak non-kidal lebih baik dibandingkan pada anak kidal.
\end{abstract}

Kata kunci: status kebersihan gigi dan mulut, anak kidal, anak non-kidal, menyikat gigi teknik kombinasi. 
Anak memiliki periode perkembangan dari masa bayi hingga usia enam tahun yang disebut dengan masa pra sekolah, kemudian berkembang ke masa sekolah dasar. Pola perkembangan anak semuanya sama tetapi kecepatan perkembangan serta kemampuan anak berbeda antara satu dengan lainnya. ${ }^{1}$ Seiring berjalannya tahap perkembangan, anak-anak mulai melakukan aktivitas seperti berbicara kalimat pendek, belajar menggambar dan menulis. ${ }^{2}$ Umumnya anak melakukan aktivitas dengan menggunakan tangan kanan. ${ }^{3}$ Di seluruh dunia sekitar 90\% menggunakan tangan kanan dan $10 \%$ menggunakan tangan kiri. ${ }^{4}$

Anak dikatakan kidal bila lebih banyak menggunakan tangan kirinya untuk melakukan aktivitas sehari-hari. ${ }^{5}$ Organorgan yang berada pada sisi kanan tubuh lebih kuat daripada organ-organ yang ada di sisi kiri. ${ }^{6}$ Pada penelitian lain tidak ditemukan kelemahan dalam perkembangan motorik anak kidal. Anak kidal beraktivitas sama seperti yang dilakukan anak non-kidal. ${ }^{7}$ Melalui perkembangan motorik kasar dan halus yang sudah lebih sempurna maka anak usia sekolah baik anak kidal maupun anak non-kidal harus dibiasakan memelihara kebersihan gigi dan mulutnya. ${ }^{8}$

Kebersihan gigi dan mulut merupakan upaya dalam menjaga kebersihan rongga mulut dan lidah dari semua kotoran atau sisa makanan. ${ }^{9}$ Kebersihan gigi dan mulut yang buruk tidak hanya menyebabkan bau mulut, kerusakan gigi dan radang gingiva, tetapi juga meningkatkan risiko penyakit jantung dan masalah kesehatan lainnya. ${ }^{10}$ Riset Kesehatan Dasar (RISKESDAS) tahun 2013 menyebutkan bahwa prevalensi penduduk yang bermasalah gigi dan mulut di Sulawesi Utara lebih besar daripada prevalensi penduduk yang bermasalah gigi dan mulut di Indonesia yaitu sebesar $31,6 \%$. Prevalensi penduduk yang bermasalah gigi dan mulut pada usia 5-9 tahun menunjukkan angka yang cukup tinggi yaitu sebesar $28,9 \% .^{11}$ Salah satu cara paling mudah dalam menjaga kebersihan gigi dan mulut yaitu dengan menyikat gigi. ${ }^{12}$

Debris atau sisa-sisa makanan dapat dibersihkan dengan cara meyikat gigi. Selain itu, menyikat gigi memiliki tujuan yaitu untuk merangsang jaringan gingiva dan melapisi permukaan gigi dengan fluor. ${ }^{13}$ Menyikat gigi dengan teknik apapun harus diperhatikan cara menyikat gigi tersebut jangan sampai merusak struktur gigi. ${ }^{14}$ Terdapat beberapa metode penyikatan gigi, yaitu: metode vertikal, metode horizontal, metode roll, metode Bass, metode Charter, metode Fones atau teknik sirkuler, dan metode Stillman. ${ }^{15}$ Hasil penelitian sebelumnya yang dilakukan oleh Suyatmi et al. ${ }^{16}$ di SD Muhammadiyah Trini Gamping Sleman Yogyakarta pada tahun 2012 menunjukkan bahwa menyikat gigi menggunakan metode kombinasi (vertikal, horizontal, dan Fones) paling efektif menurunkan skor plak.

Penelitian tentang kebersihan gigi dan mulut selalu dilakukan pada anak non-kidal sedangkan pada anak kidal belum pernah dilakukan penelitian tersebut. Penelitian ini bertujuan untuk mengetahui perbedaan kebersihan gigi dan mulut pada anak kidal dan non-kidal berusia 6-12 tahun dengan menyikat gigi menggunakan teknik kombinasi.

\section{METODE PENELITIAN}

Jenis penelitian ini ialah deskriptif dengan menggunakan desain potong lintang. Penelitian ini dilaksanakan pada bulan September 2016 di Kecamatan Kalawat, Kabupaten Minahasa Utara, Provinsi Sulawesi Utara. Populasi penelitian ini terdiri dari anak kidal dan non-kidal di Kecamatan Kalawat di lima Sekolah Dasar (SD). Berdasarkan survei awal populasi berjumlah 940 anak. Sampel penelitian ini berjumlah 60 orang anak yang terdiri dari 30 anak kidal dan 30 anak non-kidal yang berusia 6-12 tahun. Teknik pengambilan sampel yaitu total sampling.

Kriteria inklusi ialah: anak usia 6-12 tahun, bersedia menjadi sampel dalam penelitian, melakukan aktivitas menggunakan tangan kiri terutama menyikat gigi, dan minimal memiliki dua gigi indeks. Kriteria 
eksklusi ialah: dalam keadaan sakit, tidak disetujui orang tua, dan anak termasuk pengguna kedua tangan. Variabel penelitian ialah: kebersihan gigi dan mulut, menyikat gigi, anak kidal, dan anak non-kidal

Indeks yang digunakan untuk menentukan status kebersihan gigi dan mulut menurut Green dan Vermillion yaitu Oral Hygiene Index Simplified (OHI-S). $\mathrm{OHI}-\mathrm{S}$ diperoleh dengan menjumlahkan nilai indeks debris dan indeks kalkulus. Kriteria baik dengan nilai $0,0-1,2$; kriteria sedang dengan nilai $1,3-3,0$; dan kriteria buruk dengan nilai 3,1-6,0.

Menyikat gigi dengan menggunakan teknik kombinasi adalah menggabungkan teknik menyikat gigi horizontal (kirikanan), vertikal (atas-bawah), dan sirkular (memutar). Instrumen penelitian ialah formulir pemeriksaan kebersihan gigi dan mulut. Alat dan bahan yang digunakan ialah sonde, kaca mulut, pinset, alkohol, masker, handscoon, sikat gigi, pasta gigi dan disclosing solution.

Penelitian ini dilakukan setelah mendapat persetujuan dari Ketua Program Studi Pendidikan Dokter Gigi Universitas Sam Ratulangi Manado, kepala-kepala Sekolah Dasar di Kecamatan Kalawat dan orang tua dari anak yang menjadi responden. Penelitian dilakukan dengan survei awal di sekolah-sekolah SD di wilayah kecamatan Kalawat yang menjadi tempat penelitian untuk mendata anak-anak kidal dan non-kidal kemudian diseleksi berdasarkan kriteria inklusi dan eksklusi. Data yang diperoleh, diolah, dianalisis secara manual dan penyajian data dalam bentuk tabel distribusi.

\section{HASIL PENELITIAN DAN BAHASAN Profil sekolah}

SD Negeri Suwaan berlokasi di Desa Suwaan Jl. Ibu Walanda Maramis, Kecamatan Kalawat, Kabupaten Minahasa Utara dengan jumlah total 124 siswa terdiri dari 50 siswa dan 74 siswi. SDN Inpres Kolongan berlokasi di Desa Kolongan Tetempangan, Jl. Manado-Bitung, Kecamatan Kalawat, Kabupaten Minahasa Utara dengan jumlah total 542 siswa terdiri dari 267 siswa dan 275 siswi. SD Inpres Kawangkoan berlokasi di desa Kawangkoan, Jl. Kawangkoan-Kuwil Jaga II, Kecamatan Kalawat, Kabupaten Minahasa Utara dengan jumlah total 156 siswa. SD GMIM 54 Kuwil berlokasi di Desa Kuwil Jaga II, Kecamatan Kalawat, Kabupaten Minahasa Utara dengan jumlah total 74 siswa terdiri dari 43 siswa dan 74 siswi. SD Inpres Suwaan berlokasi di Desa Suwaan, Kecamatan Kalawat, Kabupaten Minahasa Utara dengan jumlah total 44 siswa terdiri dari 18 siswa dan 26 siswi.

Responden pada penelitian ini dikategorikan berdasarkan jenis kelamin, usia, status kebersihan gigi dan mulut sebelum menyikat gigi dengan teknik kombinasi (kidal dan non-kidal), dan status kebersihan gigi dan mulut sesudah menyikat gigi dengan teknik kombinasi (kidal dan non-kidal).

Tabel 1 menunjukkan bahwa jumlah responden kidal laki-laki sebanyak 11 responden (36,7\%), responden kidal perempuan sebanyak 19 responden (63,3\%), responden non-kidal laki-laki sebanyak 14 responden $(46,7 \%)$, dan responden non-kidal perempuan sebanyak 16 responden $(53,5 \%)$.

Tabel 2 menunjukkan bahwa responden kidal dan responden non-kidal jumlahnya sama banyak dari usia 6 tahun sampai usia 12 tahun. Responden terbanyak yaitu yang berusia 10 tahun berjumlah 9 responden $(30,0 \%)$ dan responden yang paling sedikit yaitu yang berusia 12 tahun sebanyak 1 responden $(3,3 \%)$.

Tabel 3 menunjukkan bahwa responden kidal dan non-kidal dalam kategori status kebersihan gigi dan mulut baik, sedang, dan buruk, sebelum menyikat gigi berjumlah sama. Paling banyak ditemukan yaitu responden dengan kategori status kebersihan gigi dan mulut baik sebanyak 26 responden $(86,7 \%)$, namun, tidak terdapat responden dalam kategori status kebersihan gigi dan mulut buruk.

Tabel 4 menunjukkan bahwa status kebersihan gigi dan mulut responden kidal dan non-kidal setelah menyikat gigi menggunakan teknik kombinasi memiliki 
nilai yang berbeda. Responden kidal dengan kategori status kebersihan gigi dan mulut baik sebanyak 29 responden $(96,7 \%)$ sedangkan, responden non-kidal sebanyak 30 responden $(100 \%)$.

Tabel 5 menunjukkan bahwa status kebersihan gigi dan mulut responden kidal sebelum menyikat gigi yaitu 0,7 dengan kategori baik, sedangkan pada anak non- kidal, status kebersihan gigi dan mulut sebelum menyikat gigi yaitu 0,6 dengan kategori baik. Setelah menyikat gigi, status kebersihan gigi dan mulut responden kidal yaitu 0,3 dengan kategori baik, sedangkan status kebersihan gigi dan mulut pada responden non-kidal setelah menyikat gigi yaitu 0,2 dengan kategori baik.

Tabel 1. Distribusi responden berdasarkan jenis kelamin

\begin{tabular}{lcccc}
\hline Jenis kelamin & \multicolumn{2}{c}{ Kidal } & \multicolumn{2}{c}{ Non-kidal } \\
& $\mathrm{n}$ & $\%$ & $\mathrm{n}$ & $\%$ \\
\hline Laki-laki & 11 & 36,7 & 14 & 46,7 \\
Perempuan & 19 & 63,3 & 16 & 53,3 \\
Total & 30 & 100,0 & 30 & 100,0 \\
\hline
\end{tabular}

Tabel 2. Distribusi responden berdasarkan usia

\begin{tabular}{ccccc}
\hline Usia & \multicolumn{2}{c}{ Kidal } & \multicolumn{2}{c}{ Non-kidal } \\
(Tahun) & $\mathrm{n}$ & $\%$ & $\mathrm{n}$ & $\%$ \\
\hline 6 & 6 & 20,0 & 6 & 20,0 \\
7 & 2 & 6,7 & 2 & 6,7 \\
8 & 5 & 16,7 & 5 & 16,7 \\
9 & 4 & 13,3 & 4 & 13,3 \\
10 & 9 & 30,0 & 9 & 30,0 \\
11 & 3 & 10,0 & 3 & 10,0 \\
12 & 1 & 3,3 & 1 & 3,3 \\
Total & 30 & 100,0 & 30 & 100,0 \\
\hline
\end{tabular}

Tabel 3. Status kebersihan gigi dan mulut responden sebelum menyikat gigi

\begin{tabular}{lcccc}
\hline $\begin{array}{l}\text { Status kebersihan } \\
\text { gigi dan mulut }\end{array}$ & $\mathrm{n}$ & $\%$ & $\mathrm{n}$ & $\%$ \\
\hline Baik & 26 & 86,7 & 26 & 86,7 \\
Sedang & 4 & 13,3 & 4 & 13,3 \\
Buruk & 0 & 00,0 & 0 & 00,0 \\
Total & 30 & 100,0 & 30 & 100,0 \\
\hline
\end{tabular}

Tabel 4. Status kebersihan gigi dan mulut responden setelah menyikat gigi

\begin{tabular}{lcccc}
\hline Status kebersihan & \multicolumn{2}{c}{ Kidal } & \multicolumn{2}{c}{ Non-kidal } \\
gigi dan mulut & $\mathrm{n}$ & $\%$ & $\mathrm{n}$ & $\%$ \\
\hline Baik & 29 & 96,7 & 30 & 100 \\
Sedang & 1 & 3,3 & 0 & 0 \\
Buruk & 0 & 00,0 & 0 & 0 \\
Total & 30 & 100,0 & 30 & 100 \\
\hline
\end{tabular}


Tabel 5. Status kebersihan gigi dan mulut responden kidal dan non kidal sebelum dan setelah menyikat gigi

\begin{tabular}{lcccc}
\hline \multirow{2}{*}{ Responden } & \multicolumn{4}{c}{ Status kebersihan gigi dan mulut } \\
& Sebelum menyikat gigi & Setelah menyikat gigi \\
\cline { 2 - 5 } & Skor & Kategori & Skor & Kategori \\
\hline Kidal & 0,7 & Baik & 0,3 & Baik \\
Non-kidal & 0,6 & Baik & 0,2 & Baik \\
Selisih & 0,1 & Baik & 0,1 & Baik \\
\hline
\end{tabular}

\section{BAHASAN}

Tabel 1 menunjukkan bahwa distribusi responden kidal laki-laki berdasarkan jenis kelamin sebanyak 11 responden $(36,7 \%)$ dan responden non-kidal laki-laki sebanyak 14 responden $(46,7 \%)$ sedangkan, responden kidal perempuan sebanyak 19 responden $(63,3 \%)$ dan responden nonkidal perempuan sebanyak 16 responden $(53,5 \%)$. Dwijandono ${ }^{17}$ menjelaskan bahwa perkembangan pada anak baik laki-laki maupun perempuan terjadi karena faktor kematangan, belajar atau pengalaman, faktor-faktor dalam (bawaan) dan faktor luar (lingkungan). ${ }^{17,18}$

Tabel 2 menunjukkan bahwa distribusi responden kidal dan non-kidal berdasarkan usia dan dalam jumlah perbandingan responden yang sama. Responden kidal paling banyak ditemukan pada usia 10 tahun sebanyak 9 responden (30,0\%). Menurut Atmodiwirjo, ${ }^{19}$ setiap fase perkembangan memiliki ciri dan sifat yang khas sehingga ada tingkah laku yang dianggap sebagai tingkah laku buruk atau kurang sesuai yang sebenarnya. Lestari ${ }^{20}$ menjelaskan bahwa kecepatan perkembangan pada sesuatu aspek pada tiap orang berbeda-beda. Anak-anak dengan umur yang sama tidak selalu mencapai titik atau tingkat perkembangan fisik, mental, sosial dan emosi yang sama.

Tabel 3 menunjukkan bahwa distribusi responden kidal dan non-kidal berdasarkan status kebersihan gigi dan mulut kategori baik sebelum menyikat gigi menggunakan teknik kombinasi, memiliki responden yang paling banyak yaitu 26 responden $(86,7 \%)$. Menjaga kesehatan gigi anak merupakan salah satu hal yang tidak dapat kita abaikan. Penelitian yang dilakukan oleh Yohanes et al. $^{21}$ menyebutkan bahwa menjaga kebersihan gigi dan mulut pada usia sekolah merupakan salah satu cara dalam meningkatkan kesehatan pada usia dini.

Tabel 4 menunjukkan bahwa distribusi responden non-kidal berdasarkan status kebersihan gigi dan mulut kategori baik setelah menyikat gigi menggunakan teknik kombinasi lebih banyak, yaitu 30 responden (100\%) dibandingkan responden kidal yaitu sebanyak 29 responden $(96,7 \%)$. Beberapa masalah gigi anak yang sering terjadidisebabkan apabila anak belum bisa membersihkan atau menyikat giginya dengan baik. Karies atau gigi berlubang merupakan masalah yang paling sering dikeluhkan anak. Penyebabnya yaitu plak yang tidak dibersihkan sehingga muncul bakteri. Cara yang paling sederhana untuk menjaga kebersihan gigi dan mulut yaitu dengan cara menyikat gigi. Penelitian yang dilakukan oleh Suyatmi et al. ${ }^{16}$ di SD Muhammadiyah Trini Yogyakarta tahun 2012 menjelaskan bahwa menyikat gigi menggunakan teknik kombinasi paling efektif menurunkan skor plak. Pada umumnya, aktivitas anak seperti menyikat gigi dan menulis dominan menggunakan tangan kanan. Selain itu, gigi yang disikat kurang dari 2 menit tidak efektif membersihkan plak. Menyikat gigi yang tepat membutuhkan waktu minimal 2 menit. ${ }^{14,16}$

Penelitian ini menunjukkan bahwa nilai rerata responden kidal sebelum menyikat gigi yaitu 0,7 , sedangkan pada 
responden non-kidal nilai rerata yaitu 0,6. Kedua responden ini memiliki kategori yang sama yaitu kategori baik, namun memiliki nilai rerata yang berbeda yaitu 0,7 dan 0,6 dengan selisih 0,1 . Nilai rerata responden kidal setelah menyikat gigi yaitu 0,3 sedangkan responden non-kidal memiliki nilai rerata 0,2 . Setelah menyikat gigi, responden kidal dan non-kidal juga memiliki kategori yang sama yaitu kategori baik namun memiliki nilai rerata yang berbeda yaitu 0,3 dan 0,2 dengan selisih 0,1 . Hal ini menunjukkan bahwa status kebersihan gigi dan mulut sebelum dan sesudah menyikat gigi menggunakan teknik kombinasi pada responden non-kidal lebih baik dibandingkan dengan responden kidal. Hardryck dan Petrinovich $^{6}$ menjelaskan bahwa penggunaan tangan merupakan soal kebiasaan. Ardyan ${ }^{14}$ menyatakan bahwa gigi yang disikat kurang dari 2 menit tidak efektif membersihkan plak. Menyikat gigi yang tepat membutuhkan waktu minimal 2 menit.

\section{SIMPULAN}

Dari hasil penelitian dan bahasan dapat disimpulkan bahwa berdasarkan cara menyikat gigi dengan teknik kombinasi, anak non-kidal memiliki status kebersihan gigi dan mulut yang lebih baik dibandingkan dengan anak kidal.

\section{SARAN}

1. Orang tua dapat membantu anakanaknya untuk menjaga dan merawat kebersihan gigi dan mulut sejak dini dengan cara menyikat gigi 2 kali sehari yaitu pagi sesudah sarapan dan malam hari sebelum tidur.

2. Penelitian ini dapat menjadi acuan referensi bagi penelitian selanjutnya mengenai status kebersihan gigi dan mulut berdasarkan cara menyikat gigi menggunakan teknik kombinasi pada anak kidal dan non kidal dengan jumlah responden yang lebih besar.

DAFTAR PUSTAKA

1. Prijambodo HSW. Bunga Rampai
Hukum dan Filsafat di Indonesia: Sebuah Catatan Pemikiran. Semarang: Deepublilsh, 2015; p. 44.

2. Saktiyono. IPA Biologi Jilid 2 . Wijayanti ChE, Khairunisa A, editor. Esis, 2004; p. 24.

3. Kail RV, Cavanaugh JC. Human Development: a life-span. Florida: University of West Florida, 2007; p. 111.

4. Bhattacharya A, McGlothlin JD. Occupational Ergonomics: Theory and Applications (2nd ed). West Lafayette: CRC, 2012; p. 330.

5. Sampeliling AR. Keadilan untuk si kidal. 2014. [cited 2016 April 12]. Available from: https://www.selasar.com/budaya/kea dilan-untuk-si-kidal.

6. Hardyck C, Petrinovich LF. Left handedness. Psychol Bull. 1977;84:387-390.

7. Charlesworth R. Cengage Advantage Books: Understanding Child Development, 2010; p. 363. ISBN10: 113396379X

8. Damayanti D. Makanan Anak Usia Sekolah: Tips Memberi Makan Anak Usia Sekolah. Jakarta: Gramedia, 2011; p. 17.

9. Yanti F. Menjaga dan merawat kesehatan mulut dan gigi. 2016. [cited 2016 Mei 8]; Available from: http://www.sehate.com/2016/01/men jaga-dan-merawat-kesehatan-mulutgigi.html.

10. Ardianto B. Kerusakan gigi dan penyakit jantung. 2013. [cited 2016 May 8]; Available from: http://bramardianto.com/kerusakangigi-dan-penyakit-jantung.html.

11. Badan Penelitian dan Pengembangan Kesehatan Kementerian Kesehatan RI. Riset Kesehatan Dasar (RISKESDAS). 2013. h. 148

12. Filloph A. 5 cara menjaga kesehatan gigi dan mulut paling mudah.2015. [cited 2016 Mei 8]; Available from: http://www.duniainformasikesehatan. com/2015/08/5-cara-menjaga kesehatan-gigi-dan-mulut.html. 
13. Amelia A. Cara menghilangkan karang gigi secara alami dan mudah. Juli 25, 2015. [cited 2016 May 8]. Available from: http://sehatsatu.com/caramenghilangkan-karang-gigi-secaraalami/

14. Ardyan GR. Serba Serbi Kesehatan Gigi dan Mulut (cetakan 1)., Handayani NP, penyunting. Jakarta: Bukune, 2010; p. 24.

15. Hiremath SS. Textbook of Preventive and Community Dentistry. India: Elsevier, 2011; p.201, 415.

16. Suyatmi D, Ediati S, Purwati DE. Sikat gigi metode kombinasi efektif menurunkan skor plak. Jurnal Teknologi Kesehatan. 2013;9(2).

\section{Dwijandono SEW. Psikologi} Pendidikan. Jakarta: Grasindo, 2002; p. 71 .
18. Gunarsa SD. Dasar dan Perkembangan Teori Anak. Jakarta: Gunung Mulya, 2008; p. 31.

19. Atmodiwirjo ET. Perkembangan anak: Suatu tinjauan dari sudut psikologi perkembangan. In: Gunarsa SD, Gunarsa YSD, editors. Psikologi Perkembangan Anak dan Remaja Jakarta: Gunung Mulia, 2008; p. 5-6.

20. Lestari S. Psikologi Keluarga: Penanaman Nilai dan Penanganan Konflik dalam Keluarga. Jakarta: Prenada Media Group, 2015; p. 47.

21. Yohanes IG, Pandelaki K, Mariati NW. Hubungan pengetahuan kebersihan gigi dan mulut dengan status kebersihan gigi dan mulut pada siswa SMAN 9 Manado. eG. 2013;1(1). 